ISSN 0258-7122

Bangladesh J. Agril. Res. 40(4): 537-550, December 2015

\title{
GENOTYPIC VARIATIONS IN GROWTH, YIELD AND YIELD COMPONENTS OF SOYBEAN GENOTYPES UNDER DROUGHT STRESS CONDITIONS
}

\author{
J. A. ChOWDHURY ${ }^{1}$, M. A. KARIM ${ }^{2}$, Q. A. KHALIQ ${ }^{2}$ \\ A. R. M. SOLAIMAN ${ }^{3}$ AND J. U. AHMED ${ }^{4}$
}

\begin{abstract}
A pot experiment was carried out in a venylhouse at Bangabandhu Sheikh Mujibur Rahman University during 2012 to investigate the growth, yield and yield contributing characters of ten selected soybean genotypes viz. Shohag, BARI Soybean-6, BARI Soybean-5, BD2331, BD2329, BD2336, BD 2340, BGM2093, G00015 and BGM2026 under drought stress and control conditions. Plant height, number of leaves, leaf area, shoot and root dry weight of all the genotypes were significantly affected by the stress. Among the genotypes Shohag, BARI Soybean-6 and BD2331 were found tolerant in relation to the growth under water stress conditions. The reduction in RGR values was more in the susceptible genotypes at the later stages of growth than in the tolerant genotypes. Seed yield of the genotypes was reduced from 42 to $68 \%$ due to drought (water) over non-stress. Susceptible genotypes showed greater reduction in seed yield than the tolerant genotypes.
\end{abstract}

\section{Introduction}

Soybean, a grain legume, is one of the most important oilseed crops of the world. It is the world's leading economic oilseed crop (Manavalan et al., 2009). It is also an important source of plant protein of the people in semi-arid and tropical regions. It has a great value as food, feed and fuel. The production of the crop is often limited by the erratic nature of rainfall. It is reported that water stress affects soybean production worldwide. Among the crops, soybean has the highest sensitivity to drought (Maleki et al., 2013). Drought may reduce yield of soybean by about 40\% (Specht et al., 1999).

In Bangladesh, soybean is planted during post-monsoon when stored soil moisture rapidly declines and the crop encounters drought at the reproductive stage. Plant growth is affected by moisture stress including leaf expansion which is reduced due to sensitivity of cell growth to water stress. Reduction in leaf area reduces crop growth and thus affects biomass production (Brown et al., 1985). Shoot biomass accumulation is considered an important trait to attain high seed

${ }^{1}$ Senior Scientific Officer, Agronomy Division, Bangladesh Agricultural Research Institute (BARI), Gazipur-1701, ${ }^{2}$ Professor, Department of Agronomy, Bangabandhu Sheikh Mujibur Rahman Agricultural University (BSMRAU), Gazipur-1706, ${ }^{3}$ Professor, Department of Soil Science, BSMRAU, Gazipur-1706, ${ }^{4}$ Professor, Department of Crop Botany, BSMRAU, Gazipur-1706. 
yield in grain legumes (Saxena et al., 1990). Significant differences have been observed for shoot and root biomass accumulation among soybean cultivars grown under severe drought stress. Root have an essential role in tolerating drought as they are the main organs responsible for sourcing valuable water (Eureka et al., 2000). Yordanov et al., (1997) claimed that water stress reduces the biomass, seed yield, number of pods in main stem, pod and seed number per plant.

The objective of this study was to assess the morphological growth parameters of ten soybean genotypes subjected to drought stress at different growth stages and to identify the genotype that is most sensitive and most tolerant to water stress.

\section{Materials and Methods}

The experiment was conducted in a venylhouse constructed at the Environmental Stress Research Site in Agronomy farm of Bangabandhu Sheikh Mujibur Rahman Agricultural University, Gazipur during February to May 2012. Six relatively tolerant soybean genotypes viz., Shohag, BARI Soybean-6, BARI Soybean-5, BD2331, BD2329 and BD2336 and four susceptible viz, BD2340, BGM2093, G00015 and BGM2026 altogether selected from the previous experiment which were grown in plastic pots. The soil of the pot was filled with mixture of soil and cow dung at a ratio of $4: 1$. Pot contained $12.0 \mathrm{~kg}$ of soil which was equivalent to $9 \mathrm{~kg}$ oven dry soil and holds about $28 \%$ moisture at field capacity (FC). Soil use in the plastic pot was sandy loam and was fertilized uniformly with $0.15,0.18,0.36$ and $0.1 \mathrm{~g}$ urea, triple super phosphate, muriate of potash and gypsum corresponding to $24-30-60-15 \mathrm{~kg}$ NPK and $\mathrm{S}$ hectare $^{-1}$, respectively. Total amount of all fertilizers were mixed with soil before the sowing of seeds.

Six seeds of each genotype were sown in each pot on 2 February 2012 and later thinned to three healthy seedlings per pot. Most of the seedlings emerged within 7 days after sowing. Plants of each pot received adequate watering regularly to maintain optimal soil moisture until the water stress treatment was imposed. Adequate plant protection measures were taken to keep the plants free from diseases, insects and weeds through the growing season.

Plants of all the genotype were subjected to two levels of water regime viz., $\mathrm{S}_{0}=$ Non-stress (Control); water was applied as and when it is required and $\mathrm{Sw}=$ Drought stress (Water stress) throughout the growing period; pots were irrigated with water at $50 \%$ field capacity at appearance of wilting symptom. The experiment was laid out in a Completely Randomized Design with four replications. Three plants pot $^{-1}$ considered as one replication. After 21 days after emergence (DAE), water stress treatments were applied. 
Total dry matter of shoot and root was measured at different growth stages (vegetative, flowering and pod filling stages) by oven drying at $70^{\circ} \mathrm{C}$ to a constant weight. For each and every sampling of all treatments four times number of replicated pots were maintained. Roots were washed thoroughly in tap water and blotted dry before drying. The leaf area plant $^{-1}$ was measured with an automatic area meter (Model AAM-8, Hayashi denko, Japan) at vegetative, flowering and pod development stages. Yield and yield components were also determine at harvest. Relative growth rate (RGR) was calculated by using the following formula (Gardner et al., 1985):

$$
\mathrm{RGR}=\frac{\mathrm{LnW}_{2}-\mathrm{Ln} \mathrm{W}_{1}}{\mathrm{~T}_{2}-\mathrm{T}_{1}} \mathrm{gg}^{-1} \mathrm{day}^{-1}
$$

Where, $\mathrm{W}_{1}=$ dry weight of plant at time $\mathrm{T}_{1}$

$$
\begin{aligned}
& \mathrm{W}_{2}=\text { dry weight of plant at time } \mathrm{T}_{2} \\
& \mathrm{Ln}=\text { natural logarithm }
\end{aligned}
$$

Yield contributing characters viz. number of pods plant-1, seeds pod-1, 100 seed weight and seed yield were measured at harvest. The recorded data were analyzed by 'MSTAT-C' statistical package. The difference between the treatments means were compared by Least Significant Difference (LSD) test (Gomez and Gomez, 1983).

\section{Results and Discussion}

\section{Plant height}

Drought significantly decreases the plant height of soybean genotypes. Plant height of ten soybean genotypes showed significant differences under both nonstress (NS) and water stress environments at all the growth stages (Table 1.). Under NS environment, BGM2026 produced the maximum plant height (50.42 $\mathrm{cm}$ ) at vegetative stage which was followed by BARI Soybean-5 and G00015 but under water stress environment, BD 2331 obtained the maximum plant height $(41.63 \mathrm{~cm})$ which was identical with BGM2026. The shortest plant was recorded from BGM2093 $(32.84 \mathrm{~cm})$ under water stress condition. But from flowering stage to maturity, all the genotypes under non-stress environment produced significantly taller plants than that under water stress environment. The genotype BGM2026 attained the maximum height at non-stress environment but under water stress environment, BARI Soybean- 6 produced the tallest plant followed by Shohag. Under water stress environment, BGM2026 was affected severely which produced the shortest plant. It was also observed that irrespective of genotype, plant height changed with the advancement of growth stages in both the environments. Plant height `increased sharply from vegetative to pod 
development stage and thereafter slowly up to maturity stage. Reduction in plant height was more at maturity stage irrespective of genotypes.

Table 1. Plant height at different growth stages in soybean genotypes under nonstress and water stress conditions.

\begin{tabular}{|c|c|c|c|c|c|c|c|c|}
\hline \multirow{3}{*}{ Genotypes } & \multicolumn{8}{|c|}{ Plant height $(\mathrm{cm})$} \\
\hline & \multicolumn{2}{|c|}{$\begin{array}{l}\text { at vegetative } \\
\text { stage }\end{array}$} & \multicolumn{2}{|c|}{$\begin{array}{l}\text { at flowering } \\
\text { stage }\end{array}$} & \multicolumn{2}{|c|}{$\begin{array}{c}\text { at pod } \\
\text { development } \\
\text { stage }\end{array}$} & \multicolumn{2}{|c|}{ at maturity stage } \\
\hline & $\begin{array}{l}\text { Non- } \\
\text { stress }\end{array}$ & $\begin{array}{l}\text { Water } \\
\text { stress }\end{array}$ & $\begin{array}{l}\text { Non- } \\
\text { stress }\end{array}$ & $\begin{array}{l}\text { Water } \\
\text { stress }\end{array}$ & $\begin{array}{l}\text { Non- } \\
\text { stress }\end{array}$ & $\begin{array}{l}\text { Water } \\
\text { stress }\end{array}$ & $\begin{array}{l}\text { Non- } \\
\text { stress }\end{array}$ & $\begin{array}{l}\text { Water } \\
\text { stress }\end{array}$ \\
\hline Shohag & 43.76 & 35.06 & 63.28 & 53.2 & 68.83 & 55.4 & 75.97 & 60.87 \\
\hline BD2329 & 42.35 & 33.03 & 62.1 & 51.97 & 70.12 & 55.31 & 74.22 & 57.2 \\
\hline $\begin{array}{l}\text { BARI } \\
\text { Soybean-5 }\end{array}$ & 49.39 & 35.77 & 64.56 & 50.59 & 69.75 & 54.17 & 77.31 & 59.27 \\
\hline $\begin{array}{l}\text { BARI } \\
\text { Soybean-6 }\end{array}$ & 45.57 & 40.35 & 67.6 & 55.11 & 74.67 & 59.22 & 78.74 & 64.51 \\
\hline BD2340 & 41.42 & 38.8 & 57.43 & 47.94 & 72.95 & 52.97 & 75.55 & 54.8 \\
\hline BD2336 & 44.74 & 39.57 & 58.18 & 45.44 & 73.54 & 52.04 & 76.68 & 58.63 \\
\hline BGM2093 & 39.27 & 32.84 & 54.58 & 46.67 & 71.85 & 53.5 & 78.38 & 57.32 \\
\hline BD2331 & 45.85 & 41.63 & 68.03 & 52.1 & 75.8 & 55.94 & 77.33 & 58.75 \\
\hline G00015 & 48.21 & 39.62 & 68.5 & 50.2 & 72.71 & 56.71 & 75.72 & 57.21 \\
\hline BGM2026 & 50.42 & 40.7 & 74.06 & 44.5 & 86.67 & 47.67 & 92.45 & 49.8 \\
\hline $\operatorname{LSD}_{(0.05)} \mathrm{SxG}$ & \multicolumn{2}{|c|}{ NS } & \multicolumn{2}{|c|}{ NS } & \multicolumn{2}{|c|}{9.917} & \multicolumn{2}{|c|}{6.136} \\
\hline $\mathrm{CV} \%$ & \multicolumn{2}{|c|}{9.58} & \multicolumn{2}{|c|}{9.86} & \multicolumn{2}{|c|}{9.38} & \multicolumn{2}{|c|}{5.46} \\
\hline
\end{tabular}

$\mathrm{S}=$ Stress, $\mathrm{G}=$ Genotypes, NS=Not significant

At maturity stage extent of plant height reduction under two moisture regimes are presented in Fig. 1. The reduction percent in plant height was found minimum in BARI Soybean-6 (18.07\% reduction) and maximum in the genotype BGM2026 $(46.13 \%)$ due to water stress. The differences in plant height reduction among the genotypes mainly due to genotypic differences. Water stress induced reduction in plant height was also observed by Khan et al. (2014) in soybean. The decrease in plant height could be resulted from a reduction in plant photosynthetic efficiency as reported by Hamid et al. (1990). It also might be due to decrease in relative turgidity and dehydration of protoplasm which is associated with a loss of turgor and reduced expansion of cell and cell division (Arnon, 1972). 


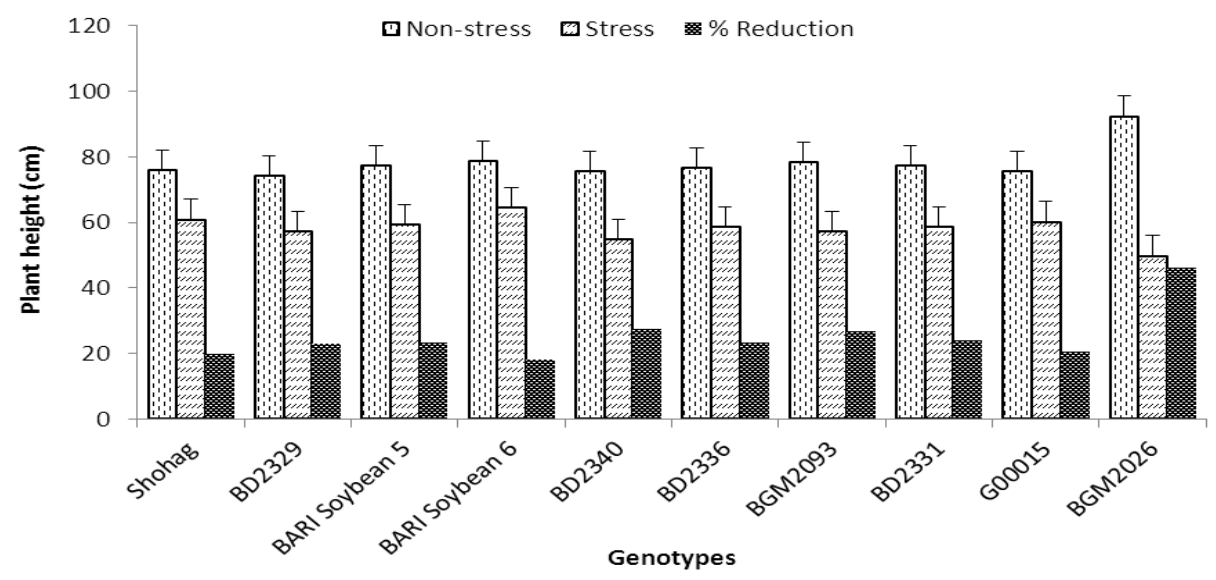

Fig 1. Extent of plant height reduction at maturity under non-stress and water stress environments of 10 selected soybean genotypes. (Vertical bar represent LSD value at $5 \%$ level of significant.)

Table 2. Leaf number at flowering and pod development stages in soybean genotypes under non-stress and water stress conditions.

\begin{tabular}{|c|c|c|c|c|c|c|}
\hline \multirow{3}{*}{ Genotype } & \multicolumn{6}{|c|}{ Total leaf number } \\
\hline & \multicolumn{3}{|c|}{ Flowering stage } & \multicolumn{3}{|c|}{ Pod development stage } \\
\hline & $\begin{array}{l}\text { Non- } \\
\text { stress }\end{array}$ & $\begin{array}{l}\text { Water } \\
\text { stress }\end{array}$ & $\begin{array}{c}\% \\
\text { reduction }\end{array}$ & $\begin{array}{l}\text { Non- } \\
\text { stress }\end{array}$ & $\begin{array}{l}\text { Water } \\
\text { stress }\end{array}$ & $\begin{array}{c}\% \\
\text { reduction }\end{array}$ \\
\hline Shohag & 25 & 20 & 20 & 30 & 22 & 26 \\
\hline BD2329 & 24 & 18 & 25 & 29 & 20 & 31 \\
\hline BARI Soybean-5 & 26 & 18 & 30 & 34 & 22 & 35 \\
\hline BARI Soybean-6 & 26 & 22 & 15 & 28 & 23 & 17 \\
\hline BD2340 & 24 & 17 & 29 & 30 & 21 & 30 \\
\hline BD2336 & 23 & 14 & 39 & 28 & 16 & 42 \\
\hline BGM2093 & 22 & 14 & 36 & 29 & 17 & 41 \\
\hline BD2331 & 24 & 17 & 29 & 28 & 18 & 35 \\
\hline G00015 & 19 & 13 & 31 & 26 & 17 & 34 \\
\hline BGM2026 & 29 & 14 & 51 & 37 & 15 & 59 \\
\hline $\mathrm{LSD}_{(0.05)} \mathrm{S} \times \mathrm{G}$ & \multicolumn{2}{|c|}{ NS } & \multicolumn{4}{|c|}{5.513} \\
\hline $\mathrm{CV} \%$ & \multicolumn{2}{|c|}{15.23} & & \multicolumn{2}{|c|}{13.44} & \\
\hline
\end{tabular}

$\mathrm{S}=$ Stress, $\mathrm{G}=$ Genotype, NS=Not significant

\section{Leaf number plant $^{-1}$}

Decrease in leaf number was observed at two growth stages under water stress environments (Table 2.). Genotypic variations in number of leaves were also found under both non-stress and water stress environment. In all the genotypes 
decrease in leaf number was higher at pod development stage, than that at flowering stage. Water stress condition reduces the leaf number because drought stress reduces leaf initiation and accelerates leaf senescence. At flowering stage, reduction percent varied from 15 to $51 \%$, whereas it was 17 to $59 \%$ at pod development stage. Razakou et al. (2013) observed 5 to 64\% reduction in leaf number in cowpea. Under water stress condition, lowest number of leaf was found in BGM2026 genotype but at non-stress condition, it produced the highest number of leaf. Due to water stress the less affected varieties were BARI Soybean-6 and Shohag. Reduction in leaf number occurred may be due to less number of leaf initiation (Thrikawela, and Bandara, 1992)

\section{Leaf area}

Reduction in leaf area is convenient morphological parameters for measuring drought stress experienced by the plant ( $\mathrm{Ku}$ et al., 2013). Water stress significantly reduced the total leaf area. Under stress, drought tolerant soybean cultivars exhibited a larger leaf area when compared with less tolerant cultivars (Moreira et al., 2010). Leaf area of ten soybean genotypes at different growth stages under non-stress and water stress environments showed significant differences (Table 3.). At vegetative stage, the reduction of leaf area varied from 8.04 to $22.63 \%$ and reduction percent does not show any trend among tolerant and susceptible genotypes. But at the later stages of growth these situations were changed. With the advancement of growth the susceptible genotype showed the higher reduction than tolerant genotypes. Under non-stress condition highest leaf area was found in BGM2026 at both flowering and pod development stages but not under stress condition. Under stress condition Shohag produced the highest leaf area. In case of reduction percent BGM2026 showed the highest reduction and BARI Soybean- 6 showed the lowest reduction in leaf area at both flowering and pod development stages. Less leaf expansion, leaf growth reduction and leaf senescence acceleration might be responsible for lower leaf area. Khan et al. (2014) in soybean and Samson and Helmut (2007) in cowpea reported earlier that water deficit stress reduced significantly the total leaf area. Krishnamoorthy (1993) reported that water stress causes a reduction in the size of leaves as because cell division in the leaf primordial ceases due to water stress. According to Ludlow and Muchow (1990) reduced leaf growth and accelerated leaf senescence is common responses to water deficits and the parameters both reduce leaf area. 
Table 3. Leaf area at different growth stages in soybean genotypes under non-stress and water stress conditions

\begin{tabular}{|c|c|c|c|c|c|c|}
\hline \multirow{3}{*}{ Genotypes } & \multicolumn{6}{|c|}{ Leaf area $\left(\mathrm{cm}^{2}\right.$ plant $\left.^{-1}\right)$} \\
\hline & \multicolumn{2}{|c|}{ Vegetative stage } & \multicolumn{2}{|c|}{ Flowering stage } & \multicolumn{2}{|c|}{$\begin{array}{c}\text { Pod development } \\
\text { stage }\end{array}$} \\
\hline & Non-stress & $\begin{array}{l}\text { Water } \\
\text { stress }\end{array}$ & $\begin{array}{l}\text { Non- } \\
\text { stress }\end{array}$ & $\begin{array}{l}\text { Water } \\
\text { stress }\end{array}$ & $\begin{array}{l}\text { Non- } \\
\text { stress }\end{array}$ & $\begin{array}{l}\text { Water } \\
\text { stress }\end{array}$ \\
\hline Shohag & 728.78 & $\begin{array}{l}650.54 \\
(10.73)\end{array}$ & 1043.0 & $\begin{array}{c}823.97 \\
(21.0)\end{array}$ & 1204.7 & $\begin{array}{l}875.69 \\
(27.31)\end{array}$ \\
\hline BD2329 & 669.21 & $\begin{array}{c}530.01 \\
(20.8)\end{array}$ & 936.12 & $\begin{array}{l}655.67 \\
(29.95)\end{array}$ & 1164.02 & $\begin{array}{l}737.66 \\
(36.62)\end{array}$ \\
\hline BARI Soybean-5 & 674.24 & $\begin{array}{l}598.91 \\
(11.17)\end{array}$ & 1027.79 & $\begin{array}{l}793.96 \\
(22.75)\end{array}$ & 1212.22 & $\begin{array}{l}842.37 \\
(30.51)\end{array}$ \\
\hline BARI Soybean-6 & 616.45 & $\begin{array}{c}566.86 \\
(8.04)\end{array}$ & 879.96 & $\begin{array}{c}747.09 \\
(15.09)\end{array}$ & 1159.4 & $\begin{array}{l}862.25 \\
(25.62)\end{array}$ \\
\hline BD2340 & 638.59 & $\begin{array}{c}581.11 \\
(9.0)\end{array}$ & 904.73 & $\begin{array}{l}653.91 \\
(27.72)\end{array}$ & 1200.3 & $\begin{array}{l}733.98 \\
(38.85)\end{array}$ \\
\hline BD2336 & 665.66 & $\begin{array}{l}515.02 \\
(22.63)\end{array}$ & 928.77 & $\begin{array}{l}606.82 \\
(34.66)\end{array}$ & 1035.28 & $\begin{array}{l}630.11 \\
(39.13)\end{array}$ \\
\hline BGM2093 & 551.96 & $\begin{array}{c}502.15 \\
(9.02)\end{array}$ & 902.9 & $\begin{array}{l}565.58 \\
(37.35)\end{array}$ & 1179.27 & $\begin{array}{l}636.64 \\
(46.01)\end{array}$ \\
\hline BD2331 & 641.32 & $\begin{array}{l}561.67 \\
(14.18)\end{array}$ & 895.79 & $\begin{array}{l}688.06 \\
(23.18)\end{array}$ & 1081.37 & $\begin{array}{l}730.79 \\
(32.41)\end{array}$ \\
\hline G00015 & 582.0 & $\begin{array}{l}497.09 \\
(14.58)\end{array}$ & 710.97 & $\begin{array}{l}527.82 \\
(25.76)\end{array}$ & 897.4 & $\begin{array}{l}593.89 \\
(33.82)\end{array}$ \\
\hline BGM2026 & 735.78 & $\begin{array}{l}539.61 \\
(26.66)\end{array}$ & 1066.19 & $\begin{array}{l}560.57 \\
(52.48)\end{array}$ & 1311.13 & $\begin{array}{l}577.98 \\
(55.91)\end{array}$ \\
\hline $\operatorname{LSD}_{(0.05)} \quad \mathrm{SxG}$ & \multicolumn{2}{|c|}{47.81} & \multicolumn{2}{|c|}{64.07} & \multicolumn{2}{|c|}{78.78} \\
\hline $\mathrm{CV} \%$ & \multicolumn{2}{|c|}{4.74} & \multicolumn{2}{|c|}{4.87} & \multicolumn{2}{|c|}{5.11} \\
\hline
\end{tabular}

$\mathrm{S}=$ Stress, $\mathrm{G}=$ Genotypes

Value in the parentheses represents the percent reduction of the parameters under water stress over non-stress.

\section{Shoot and root dry weight}

Due to water stress the reduction in shoot dry weight was not significant at vegetative stage in any genotype. But numerically, reduction was higher in G00015 followed by BGM2026 at vegetative stage (Figs. 2). At this stage BD2336 produced more shoot dry weight under stress condition than non-stress 
condition (Fig: 2). At flowering or pod development stage the reductions were conspicuous in all the genotypes due to water stress. A large reduction in

shoot dry weight was found in the genotype BGM2026 which was $33.65 \%$ at flowering, $48.29 \%$ at pod development and $58.98 \%$ at maturity stage. On the contrary, the shoot dry weight of tolerant genotypes Shohag, BARI Soybean-6, BARI Soybean-5 and BD2331 were affected the least by the stress. A similar finding was observed by Khan et al. (2014) in soybean, Eureka et al. (2000) and OO et al. (2008) in mungbean. Leaf area has been frequently reported to have a close relationship with crop growth (OO et al., 2008; Anyia and Herzog, 2004). The decrease in leaf area (Table 3 ) by the WS condition was closely related to the shoot dry weight (Figs. 2). This means that tolerant genotypes having a better sustainability in producing more leaf area to keeping a high shoot dry weight under WS condition.
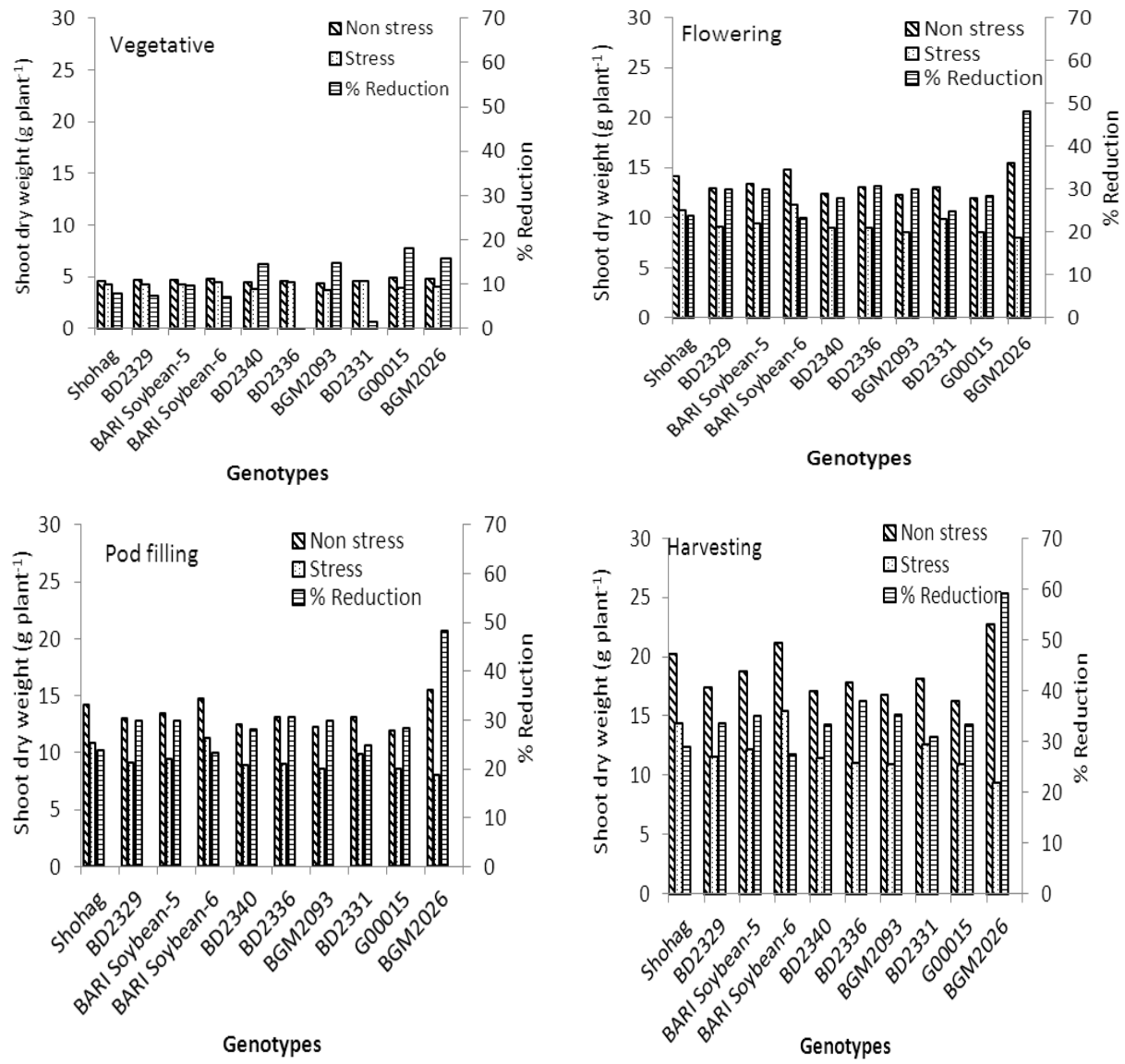

Fig. 2. Dry weight and reduction percent of shoot of 10 selected soybean genotypes at different growth stages under non-stress and water stress conditions. 

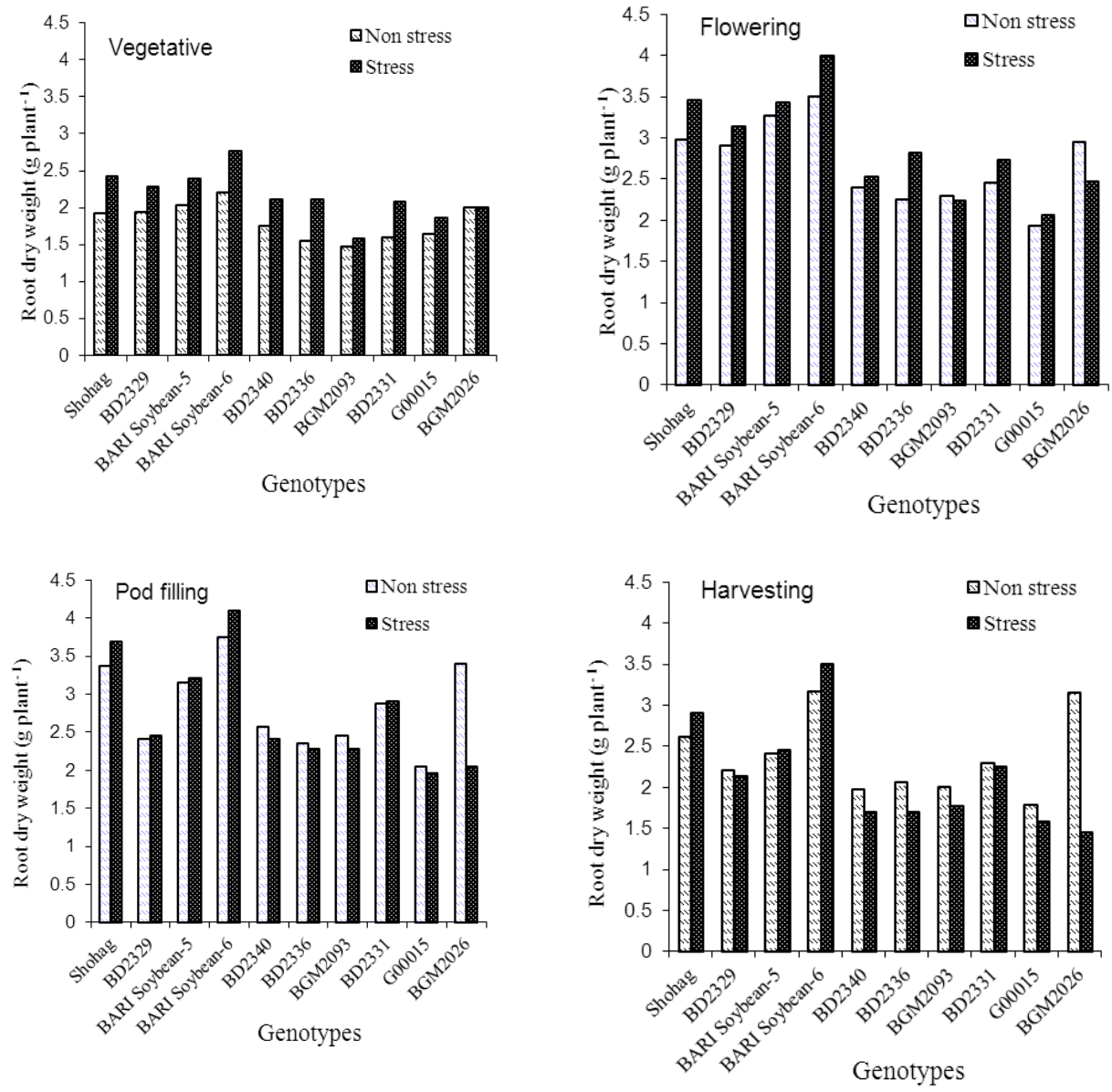

Fig. 3. Root dry weight of 10 selected soybean genotypes at different growth stages under non-stress and water stress conditions

At vegetative stage a remarkable increase in root dry weight was observed in all the genotypes under stress and non-stress conditions (Fig. 3). But root dry weight decreased under WS environment in BGM2026, BD2336, BD2340, BGM2093 and G00015 at pod development stage and onwards. At all the growth stages the genotypes Shohag and BARI Soybean-6 maintained higher root dry weight under water stress environment over non-stress. Islam et al. (2004) reported that root dry weight of bushbean measured at harvest remarkably increased with the decrease in the moisture level. Eureka et al. (2000) observed that reduction in root dry matter occurred in susceptible genotypes but tolerant genotype were able to maintain their root dry weight under drought at the level of the respective control values. The water uptake was limited by the amount of roots, and the enhancement of root growth could increase drought resistance (Klepper and 
Rickman, 1990). Increase in root biomass of water stressed genotypes may be due to ability to divert assimilates to enhance the growth of the roots so as to exploit deeper parts of the soil water (Razakou et al., 2013). Maintenance of root growth during water deficit is an obvious benefit to maintain an adequate plant water supply, and is under genetic control (Sponchiado et al., 1989). The higher value of root dry weight and less suppressed in shoot dry weight were shown in Shohag and BARI Soybean-6 that might be related to drought resistance (Fig. 3).

\section{Relative growth rate (RGR)}

Relative growth rate of all genotypes decreased with the advancement of growth stages at both the moisture regimes (Fig. 4). The RGR recorded in soybean genotypes were always higher in control than under water stress condition. Under water stress condition genotypes BD2336, BGM2093, G00015, BD2340 and BD2329 maintained relatively higher RGR at the early growth stages but at later stage higher RGR was maintained in Shohag, BARI Soybean-5,

BARI Soybean-6 and BD2331. At the later stage of the growth, the value of RGR of BGM2026

was more inhibited compared to other genotypes under water stress environment. The highest value of RGR in Shohag, BARI Soybean-5, BARI Soybean-6 and BD2331 under water stress

was an indication of their drought tolerance, while the lowest value of RGR in the genotype BGM2026 and BD2336 indicated their drought susceptibility. A similar finding was reported by Lizana et al. (2006) and Costa-Franca et al. (2000) in common bean.
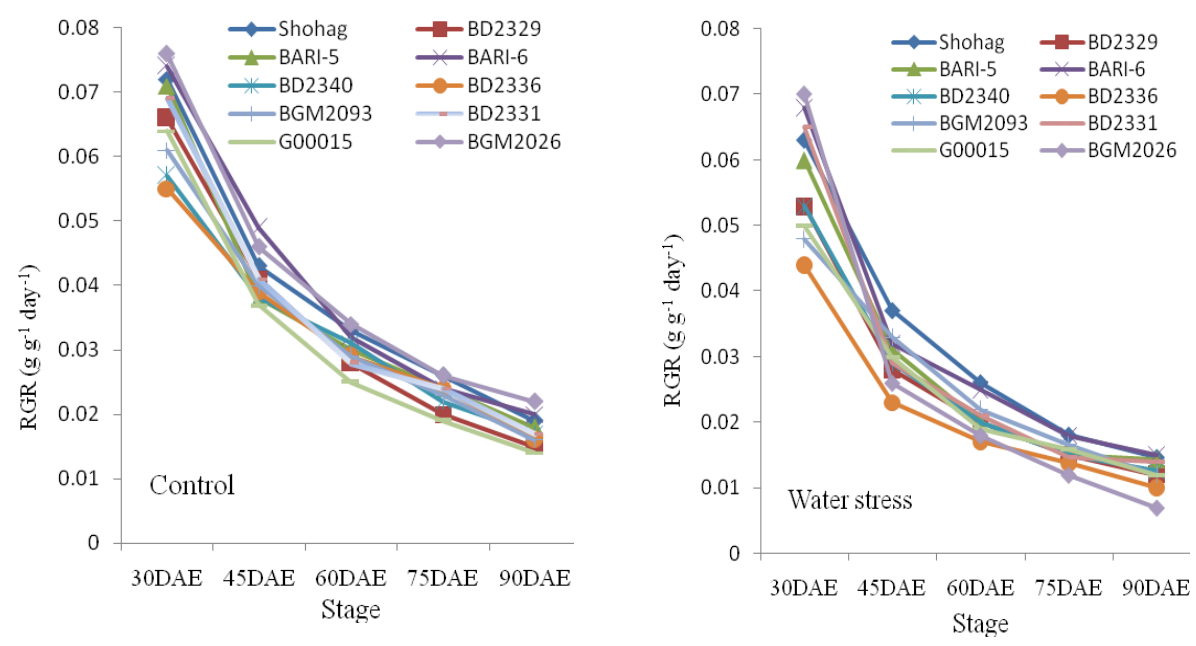

Fig 4. Relative growth rate of ten soybean genotypes at different growth stages under non-stress and water stress conditions 


\section{Seed yield and yield contributing characters}

Water stress caused significant differences in pods plant ${ }^{-1}$, seeds pod ${ }^{-1}$ and seed size of soybean genotypes (Table 4 and 5). The highest number of pod plant ${ }^{-1}$ was found in BGM2026 (59.25) which significantly differed from all other genotypes under non-stress environment. Under water stress condition, the maximum number of pod plant ${ }^{-1}$ (30.65) was obtained from BARI Soybean-6, which was statistically identical with Shohag, and BD2331. The rate of reduction was ranges from 31.37 to $55.88 \%$ the lowest where was in BARI Soybean-6 followed by BD2331 and Shohag (Table 4). The reduction in pod number plant ${ }^{-1}$ due to WS was reported earlier in french bean (Omae et al., 2005), in soybean (Kokubun et al., 2001; Liu et al., 2004) and in mungbean (Islam, 2008). The highest number of seeds pod ${ }^{-1}$ was observed in the genotype BGM2093 and the lowest from BARI Soybean-5 in both the environment. The genotype BGM2026 also produced the least number of seed $\operatorname{pod}^{-1}$ under water stress condition but not in non-stress condition. The rate of reduction varied from 2.65 to $20.43 \%$ under water stress over non-stress environment across the genotypes. The maximum reduction of seeds pods ${ }^{-1}$ (Table 4) was obtained from genotype BGM2026 (20.4\%) followed by genotypes BD2331 (11.36\%). However, the reduction rate was the lowest in BARI Soybean-5 (2.66\%). In case of seed size the rate of reduction varied from 14.06 to $26 \%$ across the genotypes. The highest 100 -seeds weight was found in G00015 at both the environments but its reduction percent was high. Lowest reduction occurred in Shohag followed by BARI Soybean-6 and BD2331. The genotype BGM2093 had the smallest seed size at both the environments.

Water stress-induced yield reduction has been reported in many crop species (Farooq et al., 2009). Seed yield plant ${ }^{-1}$ was reduced by water stress in all the soybean genotypes studied (Table 5). The rate of reduction ranged from 42.68 to $68.96 \%$ across the genotypes. The seed yield plant ${ }^{-1}$ under non-stress environment was the highest in genotype BARI Soybean-6 followed in decreasing order by BARI Soybean-5, BD2329, BGM2026, Shohag, BD2331, BD2340, G00015, BGM2093, and BD2336 genotypes. Pod number plant ${ }^{-1}$ and 100-seed weight might be responsible for highest seed yield in BARI soybean-6 and lowest in BD2336. Under water stress, the highest seed yield plant ${ }^{-1}$ was also obtained from BARI Soybean-6 followed in decreasing order by Shohag, BD2331, BARI Soybean-5, BD2339, BGM2026, BD2340, G00015, BD2336 and BGM2093. The reduction in seed yield was primarily due to a decrease in pod number plant ${ }^{-1}$. The decrease in pod number plant ${ }^{-1}$ and seed size under drought stress was possibly due to reduction of photosynthesis, translocation of assimilates and increased rate of reproductive organs abortion (Kukubun et al., 2001; Liu et al., 2003 and 2004; Tera'n and Singh, 2002). The number of seeds $\operatorname{pod}^{-1}$ and seed weight were reported to be more stable and less affected by environmental stress (Tera'n and Sigh 2002). 
Table 4. Number of pods plant ${ }^{-1}$ and seeds $\operatorname{pod}^{-1}$ in soybean genotypes under nonstress and water stress condition.

\begin{tabular}{l|c|c|c|c|c|c}
\hline \multirow{2}{*}{ Genotypes } & \multicolumn{3}{|c|}{ Pods plant $^{-1}$ (no.) } & \multicolumn{3}{c}{ Seeds pod $^{-1}$ (no.) } \\
\cline { 2 - 7 } & $\begin{array}{l}\text { Non- } \\
\text { stress }\end{array}$ & $\begin{array}{l}\text { Water } \\
\text { stress }\end{array}$ & $\begin{array}{l}\text { \% } \\
\text { Reduction }\end{array}$ & $\begin{array}{l}\text { Non- } \\
\text { stress }\end{array}$ & Water stress & $\begin{array}{l}\% \\
\text { Reduction }\end{array}$ \\
\hline Shohag & 44.16 & 29.57 & 33.03 & 2.25 & 2.15 & 4.44 \\
BD2329 & 40.25 & 22.13 & 45.01 & 2.2 & 2.1 & 4.54 \\
BARI Soybean-5 & 42.6 & 25.95 & 39.08 & 1.88 & 1.83 & 2.65 \\
BARI Soybean-6 & 44.66 & 30.65 & 31.37 & 2.2 & 2.0 & 9.09 \\
BD2340 & 41.5 & 19.14 & 53.87 & 2 & 1.92 & 4.00 \\
BD2336 & 44.58 & 24.96 & 44.01 & 2.3 & 2.2 & 4.34 \\
BGM2093 & 49.25 & 25.11 & 49.01 & 2.5 & 2.3 & 8.00 \\
BD2331 & 42.16 & 28.44 & 32.54 & 2.2 & 1.95 & 11.36 \\
G00015 & 25.66 & 12.08 & 52.92 & 2.25 & 2.04 & 9.33 \\
BGM2026 & 59.25 & 26.14 & 55.88 & 2.3 & 1.83 & 20.43 \\
\hline LSD $(0.05)$ & SxG & 9.585 & \multicolumn{5}{c}{ NS } & \\
CV\% & \multicolumn{7}{c}{16.88} & \\
\hline
\end{tabular}

$\mathrm{S}=$ Stress, $\mathrm{G}=$ Genotype, NS=Not significant

Table 5. 1000-seeds weight and seed yield plant ${ }^{-1}$ of soybean genotypes under nonstress and water stress condition.

\begin{tabular}{|c|c|c|c|c|c|c|}
\hline \multirow[b]{2}{*}{ Genotypes } & \multicolumn{3}{|c|}{ 1000-seeds weight $(\mathrm{g})$} & \multicolumn{3}{|c|}{ Seed Yield plant $^{-1}(\mathrm{~g})$} \\
\hline & $\begin{array}{l}\text { Non } \\
\text { stress }\end{array}$ & $\begin{array}{l}\text { Water } \\
\text { stress }\end{array}$ & $\begin{array}{l}\% \\
\text { Reduction }\end{array}$ & $\begin{array}{l}\text { Non } \\
\text { stress }\end{array}$ & \begin{tabular}{|l} 
Water \\
stress
\end{tabular} & $\%$ Reduction \\
\hline Shohag & 110.2 & 90.6 & 14.28 & 8.62 & 4.79 & 44.43 \\
\hline BD2329 & 110.3 & 80.8 & 22.12 & 9.11 & 3.38 & 62.90 \\
\hline BARI Soybean-5 & 120.1 & 100.0 & 17.35 & 9.18 & 4.67 & 49.12 \\
\hline BARI Soybean-6 & 110.9 & 100.2 & 14.28 & 9.22 & 5.17 & 43.92 \\
\hline BD2340 & 110.3 & 90.05 & 19.91 & 7.99 & 2.48 & 68.96 \\
\hline BD2336 & 60.08 & 40.86 & 20.06 & 5.52 & 2.18 & 60.50 \\
\hline BGM2093 & 50.89 & 40.53 & 23.08 & 5.97 & 2.18 & 63.48 \\
\hline BD2331 & 90.88 & 80.49 & 14.06 & 8.2 & 4.7 & 42.68 \\
\hline G00015 & 130.9 & 100.4 & 25.17 & 6.42 & 2.22 & 65.42 \\
\hline BGM2026 & 70.5 & 50.55 & 26 & 9.1 & 3.05 & 66.48 \\
\hline $\mathrm{LSD}_{(0.05)} \mathrm{SxG}$ & \multicolumn{2}{|r|}{ NS } & \multicolumn{4}{|c|}{0.5305} \\
\hline $\mathrm{CV} \%$ & \multicolumn{2}{|r|}{6.49} & \multicolumn{4}{|c|}{5.63} \\
\hline
\end{tabular}

$\mathrm{S}=$ Stress, $\mathrm{G}=$ Genotype, NS=Not significant.

\section{Conclusion}

The results of the study indicated that the ten genotypes showed marked variations in plant growth characters, yield and yield attributes under water stress condition. Genotypes Shohag, BARI Soybean-6 and BD2331 were relatively water stress tolerant than others in respect of physiological adaptation associated with yield attributes and seed yield under water stress condition. 


\section{References}

Anyia, A. O. and H. Herzog. 2004. Genotypic variability in drought performance and recovery in cowpea under controlled environment. J. Agron. Crop. Sci. 190: 151-159.

Arnon, I. 1972. Crop production in dry regions, Background and Principles. (Ed.): N. Polunin. Leonard Hill Book, London, 1: 203-211.

Brown, E. A., C. E. Caviness and D. A. Brown. 1985. Responses of selected soybean cultivars to soil moisture deficit. Agron. J. 77: 274-278.

Costa-Franca, M. G., A. T. P. Thi, C. Pimental, R. O. P. Rosseiello, Y. Zuily-Fodil and D. Laffray. 2000. Differences in growth and water relations among Phaseolus vulgaris cultivars in response to induced drought stress. Env. and Exp. Bot. 43: 227-237.

Eureka T. M., O. Ocampo, and P. Restituta Robles, 2000. Drought tolerance in Mung bean II. Stomatal movement, photosynthesis and leaf water potential. The Philippine Journal of Crop Science, 25:7-15.

Farooq, M., A. Wahid, N. Kobayashi, D. Fujita, S. M. A. Basra. 2009. Plant drought stress: effects, mechanisms and management. Agron. Sustain. Dev. 29: 185-212.

Gardner, F.P., R.B. Pearce and R.L. Mitchell, 1985. Physiology of Crop Pants. pp. 187208. Iowa State University Press.

Gomez, K.A. and A.A. Gomez. 1983. Statistical Procedure for Agricultural Research. John Wiley and Sons. N.Y., Pp. 20-215.

Hamid, A., F. Kubota, W. Agata, and M. Morokuma. 1990. Photosynthesis, transpiration, dry matter accumulation and yield performance of mungbean plant in response to water stress. J. Fac. Agr. Kyushu Univ. 1-2: 81-92.

Islam, M. S. 2008. Water stress tolerance of mungbean [Vigna radiata (L.) Wilczek] genotypes as influenced by plant growth regulators. A Ph.D. Dissertation, Dept. of Agronomy, Bangabandhu Sheikh Mujibur Rahman Agricultural University, Gazipur, Bangladesh.

Islam, M. S., M. M. Haque, M. M. Khan, T. Hidaka and M. A. Karim. 2004. Effect of fertilizer potassium on growth, yield and water relations of bushbean (Phaseolus vulgaris L.) under water stress conditions. Jpn. J. Trop. Agr. 48:1-9.

Khan, M. S. A., M. A. Karim and M. M. Haque. 2014. Genotypic differences in growth and ions accumulation in soybean under $\mathrm{NaCl}$ salinity and water stress conditions. Bangladesh Agron. J. 17: 47-58.

Klepper, B. and R. W. Rickman. 1990. Modeling crop root growth and function. Adv. Agron. 44: 113-132.

Kokubun, M. S., Shimada and M. Takahashi. 2001. Flower abortion caused by preanthesis water deficit is not attributed to impairment of pollen in soybean. Crop. Sci. 41: 1517-1521.

Krishnamoorthy, H. N. 1993. Water deficit and plant growth. In "Physiology of Plant Growth and Development." pp. 433-466. Pub. by Atma Ram and Sons, Delhi, India.

Ku, Y. S., W. K. A. Yeung, Y. L. Yung, M. W. Li, C. Q. Wen, X. Liu, and H. M. Lam. 2013. Drought Stress and Tolerance in Soybean. http://dx.doi.org/10.5772/52945.

Liu, F., M. N. Andersen and C. R. Jensen. 2003. Loss of pod set caused by drought stress is associated with water status and ABA content of reproductive structures in soybean. Funct. Plant Biol. 30: 271-280.

Liu, F., M. N. Andersen and C. R. Jensen. 2004. Root signal controls pod growth in drought-stressed soybean during the critical, abortion-sensitive phase of pod development. Field Crop Res. 85: 159-166.

Lizana, C., M. Wentworth, J. P. Mart'ynez, D. Villegas, R. Meneses, E. H. Murchic, C. Pastenses, B. Lercari, P. Vernieri, P. Horton and M. Pinto. 2006. Differential 
adaptation of two varieties of common been to abiotic stress. I. Effects of drought on yield and photosynthesis. J. Expt. Bot. 57: 685-697.

Ludlow, M. M. and R. C. Muchow. 1990. A critical evaluation of trits for improved crop yields in water-limited environments. Adv. Agron. 43: 107-153.

Maleki A., A. Naderi, R. Naseri, A. Fathi, S. Bahamin and R. Maleki. 2013. Physiological Performance of Soybean cultivars under drought stress. Bulletin of environment, Pharmacology and life science. 2: 38-44.

Manavalan L. P., S. K. Guttikonda, L. S. P. Tran and Nguyen. 2009. Physiological and Molecular Approaches to improve Drought Resistance in soybean. Plant Cell Physiol. 50: 1260-1276.

Moreira, R. S., M. E. Medri1, N. Neumaier, N. G. Lemos, J. A. Pimenta, S. Tobita, R. L. Brogin, F. C. Marcelino-Guimarães, M. C. N. Oliveira, J. R. B. Farias, R. V. Abdelnoor and A. L. Nepomuceno. 2010. Soybean physiology and gene expression during drought. Genet. Mol. Res. 9: 1946-1956

Omae, H., A. Kumar, Y. Egawa, K. Kashiwaba and M. Shono. 2005. Midday drop of leaf water content to drought tolerance in snap bean (Phaseolus vulgarid L.). Plant Prod. Sci. 8: 465-467.

OO, H.H., T. Araki, K. Saitou and F. Kubota. 2008. Response of growth, gas exchange and PSII electron transport in greengram (Vigna radiata L. Wilczek) varieties and other pulse species to drought and re-watering. J. Fac. Agr. Kyushu Univ. 53: 19-25.

Razakou, A I. B. Y., B. Mensah, A. S. Kiari and R. Akromah. 2013. Using morphophysiological parameters to evaluate cowpea varieties for drought tolerance. International Journal of Agricultural Science Research. 2: 153-162.

Samson, H. and H. Helmut. 2007. Drought effect on yield, leaf parameters and Evapotranspiration efficiency of cowpea. Conference of International Agricultural Research For Development. University of Kassel Witzenhause and University of Gotteingen, October 9/11/2007.

Saxena, C. M., S. N. Silim and B. K. Singh, 1990. Effect of supplementary irrigation during reproductive growth on winter and spring chickpea (Cicer arietinum) in a Mediterranean environment. J. Agri. Sci. 114: 285-293.

Specht, J. E., D. J. Hume, and S.V. Kumudini. 1999. Soybean yield potential-a genetic and physiological perspective. Crop Sci. 39: 1560-1570.

Sponchiado, B. N., J. W. White, J. A. Castillo and P. G. Jones. 1989. Root growth of four common bean cultivars in relation to drought tolerance in environments with contrasting soil types. Exp. Agric. 25: 249-257.

Tera'n, M. and S. P. Singh. 2002. Comparison of sources and lines selected for drought resistance in common bean. Crop Sci. 42: 64-70.

Thrikawela, B. S. and D. C. Bandara. 1992. Evaluation of leaf characteristics of cowpea (Vigna unguiculata L.) and Mung Bean (Vigna radiate L.) varieties for drought resistance. Tropical Agricultural Research. Vol. 4:

Yordanov, I., T. Tsonev, V. Goltsev, L. Kruleva, V. Velikova, 1997. Interactive effect of water deficit and high temperature on photosynthesis in sunflower and maize plants. 1. Chenges in the parameters of chlorophyll fluorescence induction kinetics and fluorescence quenching. Photosynthetica, 33: 391-402.

Water stress tends to increase biomass partitioning to roots, increasing the root: shoot ratio (Manavalan et al., 2009).

Plant productivity under drought stress is closely related to the processes of dry matter partitioning and the spatial and temporal root distribution (Kage et al., 2004).

Kage, H., M. Kochler and H. Stutzel. 2004. Root growth and dry matter partitioning of cauliflower under drought stress conditions: measurement and simulation. Eur. J. Agron. 20: 379-394. 